American Journal of Infectious Diseases 3 (3): 151-158, 2007

ISSN 1553-6203

(C) 2007 Science Publications

\title{
Inhibition of Cholesterol Esterification Influences Cytokine Exspression in Lypopolisaccharide-activated P388D1 Macrophages
}

\author{
${ }^{1}$ Rosa Rita Bonatesta, ${ }^{1}$ Francesca Sanna, ${ }^{1}$ Sabrina Uda, ${ }^{1}$ Bruno Frongia, ${ }^{3}$ Stefano Pintus, ${ }^{3}$ Paolo Pintus, \\ ${ }^{2}$ Maria Collu, ${ }^{1}$ Alessandra Saddi and ${ }^{1}$ Barbara Batetta \\ ${ }^{1}$ Experimental Pathology Section, Department of Biomedical Sciences and Technology, \\ ${ }^{2}$ Department of Neurosciences, University of Cagliari, Italy \\ ${ }^{3}$ Centro per le Malattie Dismetaboliche e l'Arteriosclerosi, Azienda Ospedaliera "G. Brotzu" Cagliari
}

\begin{abstract}
Several in vivo and in vitro studies have demonstrated the involvement of infectious agents in the development of atherosclerosis. However, the mechanisms by which micro-organisms induce and/or aggravate atherosclerosis, are so far unclear. Accumulation of cholesterol esters and lipid laden cell formation are hallmark of the atherogenesis, however, the possible relationship between cholesterol esterification and the signal-transducing component of LPS recognition complex inducing cytokine secretion has not been yet investigated.

In the present study, we investigated the effect of mevinolin, the ACAT inhibitor, Sandoz 58035, and plasma from statin-treated hypercholesterolemic patients on cholesterol metabolism and cytokine expression in LPS activated P388D1 macrophages. In P388D1 macrophages cholesterol synthesis and uptake, as well as cholesterol ester synthesis, were unchanged following LPSactivation. When cells were grown in presence of serum from patients under statin therapy, cholesterol esterification was lower compared to cells grown with plasma from healthy subjects, independently from the type of statin used. This effect was accompanied by inhibition of IL-1 $\beta$ expression in LPS activated cells. The ACAT inhibitor, Sandoz 58035, which completely blocked cholesterol esterification in normal and LPS-activated macrophages, prevented IL-1 $\beta$ and IL- 6 overexpression in LPS activated cells. Although preliminary, these data point to a possible relationship between cholesterol esterification and cytokine production in macrophages, prospecting new possible mechanisms by which microbial or inflammatory agents may induce and/or accelerate the atherosclerotic process.
\end{abstract}

Key words: Infections, Atherosclerosis, Macrophages, Lypopolisaccharide, Cytokines, Cholesterol Esterification.

\section{INTRODUCTION}

Inflammation as well as infectious diseases are considered $^{[1-3]}$ the new emerging risk factors for atherosclerosis. Inflammation is instrumental in developing atherosclerotic lesions and plays a crucial role in the plaque destabilisation, thus converting chronic atherosclerosis into an acute thrombo-embolic disorder. ${ }^{[4,5]}$ Humoral factors involved in destabilisation include cytokines, cyclooxygenases, matrix metalloproteinases, and tissue factor. Markers of inflammation and infection also significantly influence the occurrence of cerebrovascular events in patients with baseline asymptomatic carotid lesions ${ }^{[6]}$.
Several experimental and clinical observations have documented the involvement of infectious agents in enhancing formation of atherosclerosis lesions. The proposed mechanisms include: i) oxidation of Low Density Protein (LDL), ii) altered monocyte adhesion iii) increased production of inflammatory cytokines. However, no definite mechanism has been so far recognized to fully explain experimental and clinical observations. $^{[7,8]}$

Circulating lipopolysaccharide (LPS) is not confined to sepsis but also occurs in healthy subjects and it is often associated with accelerated progression of atherosclerosis ${ }^{[9]}$ suggesting that a blunted inflammatory response due to ineffective removal of infectious agents might be a persistent insult for the

Corresponding Author: Barbara Batetta, University of Cagliari, Department of Biomedical Sciences and Technology, Experimental Pathology Section, Via Porcell 409124 Cagliari, Italy Tel: 00390706758343 Fax: 0039070662574 
arterial wall. Furthermore, a continuous eliciting of the innate immune system may worsen inflammation in the atherosclerotic plaque leading to its swollen. The signal-transducing component of the LPS recognition complex induces cytokine secretion, ${ }^{[10,11]}$ however, although cholesterol esters and lipid laden cell formation are hallmark of the atherogenesis, the possible relationship between cholesterol esterification and inflammatory response to LPS has not been yet investigated.

In the present study we studied, in LPS activated P388D1 macrophages, the effect of mevinolin, (an inhibitor of hydroxy-methyl CoA-reductase [HMGCoA-r]), of Sandoz 58035 (an inhibitor of acylcoenzyme-A cholesterol-acyl-transferase [ACAT]), and of sera from Statin-Treated Hypercholesterolemic Patients (STHP) on cholesterol metabolism and cytokine expression. We used inhibitors of HMGCoAreductase given their effect in inhibiting both: i) cholesterol metabolism ${ }^{[12]}$ and ii) inflammatory molecule production in macrophages. ${ }^{[13]}$

\section{MATERIALS AND METHODS}

$\left[{ }^{14} \mathrm{C}\right]$-acetic acid (specific activity $2.0 \mathrm{GBq} / \mathrm{mmol}$ ) and $\left[{ }^{14} \mathrm{C}\right]$ oleic acid (specific activity $1.9 \mathrm{GBq} / \mathrm{mmol}$ ) were purchased by NEN (PerkinElmer Inc., Milano, Italy), RPMI 1640, Foetal Calf Serum (FCS), were purchased from GIBCO Laboratoires (Gaithersburg, MD, USA). Reagents for ELISA were obtained from Biosource (Prodotti Gianni, Milano, ITALY), Acetilated-LDL (ac-LDL) were purchased from Alma Export (Firenze, Italy). Mevinolin (Sigma, Milano, Italy) and Sandoz 58-035 was kindly donated by Novartis (East Hanover, N.J., USA). All other reagents were purchased from Sigma (Milano, ITALY) unless stated.

Cell culture: This study used the mouse macrophagelike cell line P388D1, obtained from American Type Culture Collection (Istituto Zooprofilattico, Brescia, Italy). Cells were grown at $37^{\circ} \mathrm{C}$, in a $5 \% \mathrm{CO}_{2}$ atmosphere to a density of $10^{6}$ cells $/ \mathrm{ml}$. Growth medium was RPMI 1640 supplemented with $10 \%$ FCS, $50 \mathrm{U} / \mathrm{ml}$ penicillin, and $50 \mathrm{U} / \mathrm{ml}$ streptomycin. For some experimental purposes medium was supplemented with $10 \%$ sera from STHP (atorvastatin or sinvastatin), as control, sera from healthy volunteers were used.

For each experiment, the appropriate concentration of drugs were used: $100 \mathrm{ng} / \mathrm{ml}$ LPS, Sandoz $580354 \mu \mathrm{M}$ solubilised in dimethyl sulfoxide $\left(\mathrm{Me}_{2} \mathrm{SO}\right.$, concentration did not exceed $\left.0.2 \%\right)$ and mevinolin $0.5 \mu \mathrm{M}$ (sodium salt of the open acid form) were added to cells.

Cell number was determined with a Coulter Counter and corrected for viability, as determined by trypan blue dye exclusion.

Preparation of human sera: Male hypercholesterolemic patients $(n=6)$ were enrolled in this study. They did not suffer of hypertension, diabetes and obesity and, beside statins, were not under any therapy. Three patients were treated with sinvastatin $(40 \mathrm{mg} / \mathrm{die})$ and the other three with atorvastatin $(40 \mathrm{mg} / \mathrm{die})$. Such statins were chosen since differ for chemical properties and half life. ${ }^{[12]}$ The blood was drown early in the morning, before drug administration. After centrifugation at $800 \mathrm{rpm}$, red cells were removed and the supernatant centrifuged at $9000 \mathrm{rpm}$ to remove platelets. Thus sera were incubated at $56^{\circ} \mathrm{C}$, for $30 \mathrm{~min}$, centrifuged and complement removed. Afterward sera were filtered in $0.2 \mu \mathrm{m}$ filter and frozen at $-80{ }^{\circ} \mathrm{C}$ until use. Sera obtained from healthy donors $(\mathrm{n}=5)$ were processed in the same way and used as control.

Determination of cholesterol synthesis: To determine the rate of cholesterol synthesis $10^{6} / \mathrm{ml}$ cells were incubated for $3 \mathrm{hrs}$ with $185 \mathrm{kBq} / \mathrm{ml}$ of sodium $\left[{ }^{14} \mathrm{C}\right]$-acetate. After incubation cells were separated by centrifugation and collected. Cell lipids were extracted with cold acetone and neutral lipids separated by thin layer chromatography (TLC) Kiesegel plates using a solvent system containing eptane/isopropylether/ formic acid $(60: 40: 2 \mathrm{v} / \mathrm{v} / \mathrm{v})$. Free cholesterol and cholesterol ester bands were identified by comparison with standards running simultaneously with samples and visualised using iodine vapour. ${ }^{[14]}$ For counting, the bands were excised and added directly to counting vials containing $10 \mathrm{ml}$ of Ultima Gold. All incubations were carried out in triplicate and the results for individual experiments are given as mean values, variation between triplicates was less than $10 \%$. All data are expressed as the rate of $\left[{ }^{14} \mathrm{C}\right]$-acetate incorporation into cholesterol per $\mu \mathrm{g}$ protein.

Determination of cholesterol esterification: Cells were incubated for 4 hours in medium containing $\left[{ }^{14} \mathrm{C}\right]$-oleate bound to bovine serum albumin (BSA). To prepare the oleate-BSA complex, $3.7 \mathrm{MBq}$ of $\left[{ }^{14} \mathrm{C}\right]$-oleic acid in ethanol (specific activity 2.035 $\mathrm{GBq} / \mathrm{mmol}$ ) was mixed with $1.4 \mathrm{mg} \mathrm{KOH}$ and the ethanol evaporated. PBS $(1.5 \mathrm{ml})$ without $\mathrm{Ca}^{2+}$ and $\mathrm{Mg}^{+}$containing $4.24 \mathrm{mg}$ BSA (fatty acid-free) was 
added and the mixture shaken vigorously. This solution was added to each well at a final concentration of $74 \mathrm{KBq} / \mathrm{ml}$. After incubation cells were washed with ice-cold PBS and lipids extracted with acetone. Neutral lipids were separated by TLC as previously described ${ }^{[14]}$ and incorporation of $\left[{ }^{14} \mathrm{C}\right]$ oleate into cholesterol esters was measured. An aliquot of cell lysate was processed for protein content $^{[15]}$.

Cellular protein isolation and Western blotting analysis: The cells were lysed in a PBS buffer containing $10 \%$ SDS, $50 \mu \mathrm{g}$ TRIS, $1 \mu \mathrm{M}$ EDTA, $\mathrm{pH}$ $7.5,50 \mu \mathrm{M}$ DTT and a protease inhibitor cocktail, at $37^{\circ} \mathrm{C}$ and homogenised by a syringe fitted with an 18 gauge needle. Protein content of each sample was determined by Bradford protein assay ${ }^{[16]}$ (Bio-Rad Laboratories, Hemel Hempstead, UK). Protein samples $(30 \mu \mathrm{g} / \mathrm{lane})$ were separated by electrophoresis (12\% SDS acrylamide gel) and transferred to a PVDF membrane (Invitrogen, Milano, Italy) by standard electro-blotting procedure. The blots were pre-treated with a solution containing $5 \%$ non fat dried milk in TBST at room temperature $(50=\mu \mathrm{M}$ TRIS-HCl, $\mathrm{pH}$ 7.6, $0.15 \mathrm{M} \mathrm{NaCl}$, and $0.05 \%$ Tween-20) for at least one hour before the addition of the primary antibodies (dilution range varying from $1: 1000$ to $1: 3000$ ) for mouse interleukin-1 $\beta$ (IL-1 $\beta$ ) and interleukin-6 (IL-6) (Santa Cruz Biotechnology, Santa Cruz, CA). After an overnight incubation the primary antibodies were removed and appropriate horseradish peroxidaseconjugated secondary antibodies (Santa Cruz Biotechnology, Santa Cruz, CA) were added in a dilution range of $1: 2500$ to $1: 5000$ for at least $1 \mathrm{~h}$ at room temperature. Proteins were detected by enhanced chemiluminescence and by exposure to X-ray film, (Amersham Pharmacia Biotech, Milano, Italy) for various times. Quantification of the protein bands was then accomplished by densitometry (Scion Imagine, $\mathrm{NIH})$.

Statistical analysis: Data analyses were performed by one- or two-way analysis of variance (ANOVA) for repeated measures followed by Newman-Keuls or Dunnett tests when appropriate. Differences were considered significant if $\mathrm{P}<0.05$.

\section{RESULTS}

Sera from STHP inhibit cholesterol esterification in P388D1 macrophages: As shown in fig. 1, except for one case, cholesterol esterification in cells cultured in presence of sera from STHP was significantly lower compared to cells growing in presence of sera from healthy volunteers. The extent of inhibition significantly differed between samples ranging from 25 to $62 \%$ vs control $(\mathrm{P}<0.05)$ independently from the statin administered.

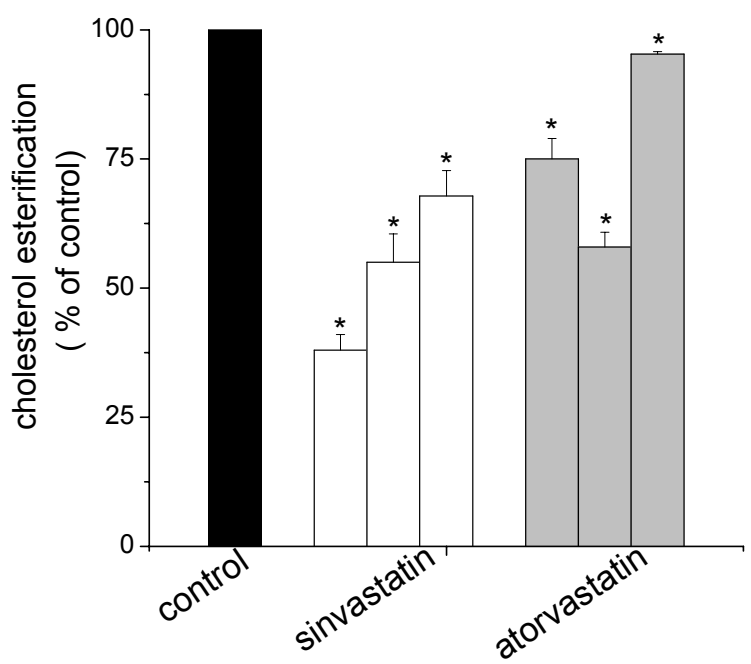

Fig 1: P388D1 cells $\left(2 \times 10^{5} / \mathrm{ml}\right)$ were incubated for 48 hours in RPMI 1640 medium containing human plasma obtained from healthy volunteers or STHP (sinvastatin and atorvastatin). Four hours before harvesting $\left[{ }^{14} \mathrm{C}\right]$-oleate was added to the culture medium. At the end of incubation cells were harvested and processed as described in Materials and Methods. Each value represents the mean \pm S.E.M. of triplicate samples. ${ }^{*} \mathrm{P}<0.05$ vs control (Dunnett's test).

Sera from STHP inhibit cholesterol esterification in LPS-activated P388D1 macrophages: As shown in fig. 2, cholesterol esterification did not change in LPS-stimulated P388D1 macrophages growing in sera from healthy volunteers. On the contrary, LPSactivated cells cultured in presence of sera from STHP showed a significant reduction of cholesterol esterification, the effect being independent from the type of statin administered $(\mathrm{P}<0.001)$. 


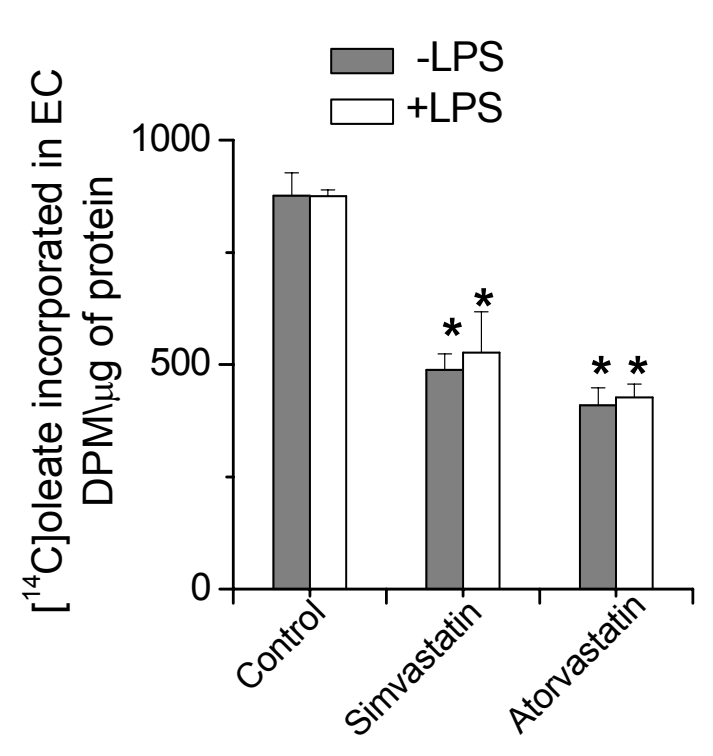

Fig 2: P388D1 cells $\left(2 \times 10^{5} / \mathrm{ml}\right)$ were incubated for $48 \mathrm{hrs}$ in RPMI 1640 medium containing human sera obtained from healthy volunteers or STHP (sinvastatin and atorvastatin) and stimulated with LPS $(100 \mathrm{ng} / \mathrm{ml})$ or vehicle (-LPS). Four hours before harvesting $\left[{ }^{14} \mathrm{C}\right]$-oleate was added to the culture medium. At the end of incubation cells were harvested and processed as described in Materials and Methods. Each value represents the mean \pm S.E.M. of triplicate samples of a representative experiment. $* \mathrm{P}<0.001$ vs control group (Dunnett's test).

Sera from STHP restrains the increase of IL-1ß
exspression in LPS-activated P388D1 macrophages: As shown in fig. 3 the incubation of LPS-activated macrophages with sera from STHP prevents the increase of IL- $1 \beta$ expression. Panel A illustrates the autoradiography of IL- $1 \beta$ in LPSactivated P388D1 cells and is representative of three different experiments. Fig. 3B shows the quantitative densitometric determination of the bands after normalisation with $\beta$-actin. The extent of inhibition of cytokine expression in LPS-activated macrophages incubated with sera from STHP varied from $40 \%$ to $70 \%$.
A

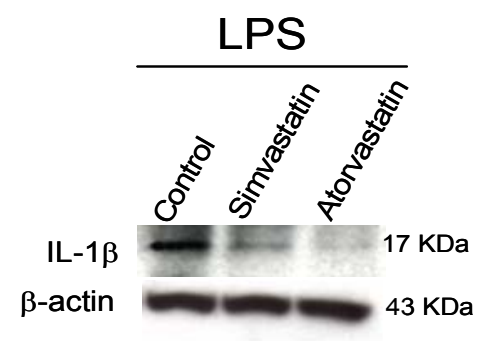

B

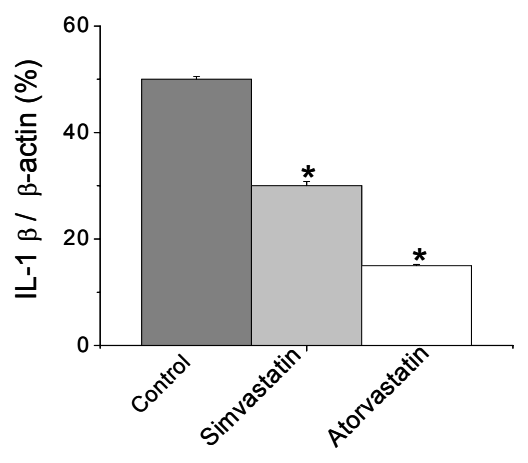

Fig 3: P388D1 cells $\left(2 \times 10^{5} / \mathrm{ml}\right)$ were incubated for 48 hours in RPMI 1640 medium containing human sera obtained from healthy volunteers or patients STHP (sinvastatin and atorvastatin) therapy and stimulated with LPS (100 ng/ml). For protein extraction and western blotting analysis see Materials and Methods (Panel A: autoradiography representative of three experiments). Quantification of the immunoblots were performed by Scion Imagine (Panel B). Each value represents the mean \pm S.E.M. of triplicate sample. ${ }^{*} \mathrm{P}<0.001$ vs control (Dunnett's test).

Mevinolin but not the ACAT inhibitor Sandoz 58035 inhibits cell proliferation and cholesterol synthesis: Fig. 4 shows that mevinolin significantly $(\mathrm{P}<0.001)$ reduced cell proliferation (panel A) in a dose-dependent manner. Concentrations of mevinolin higher than 0.5 $\mu \mathrm{M}$ were cytotoxic, thus this dose was utilized for the successive experiments. On the contrary, the ACAT inhibitor, Sandoz 58035 does not affect cell proliferation even at incubation doses up to $200 \mu \mathrm{M}$. It is worthy to note that this compound completely inhibits cholesterol esterification at $4 \mu \mathrm{M}$ dose (data not shown). As shown in the Fig. 4B mevinolin was also able to significantly inhibit cholesterol synthesis $(\mathrm{P}<0.001)$, while Sandoz 58035 was ineffective. 

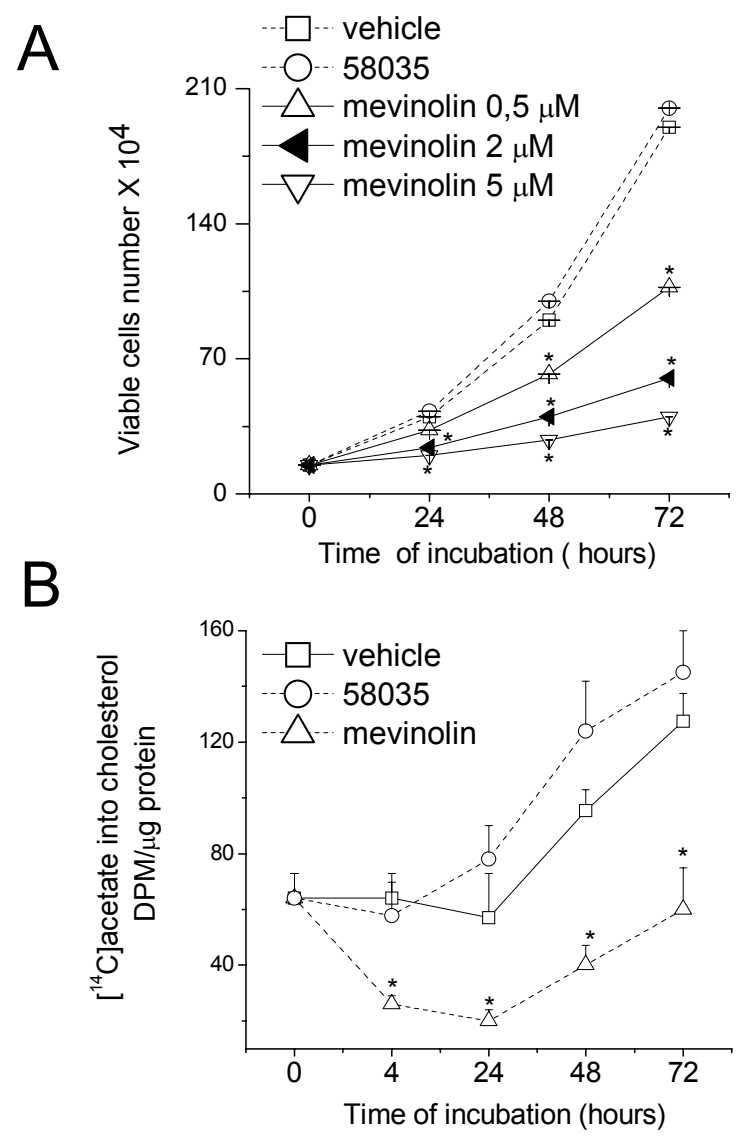

Fig 4: P388D1 cells $\left(2 \times 10^{5} / \mathrm{ml}\right)$ were incubated for $72 \mathrm{hrs}$ in RPMI 1640 medium supplemented with 10\% FCS and treated with Sandoz $58035(4 \mu \mathrm{M})$ or Mevinolin $(0.5,1$ and $2 \mu \mathrm{M})$ (Panel A). Cells were harvested at the indicated times and cell number evaluated. Panel B. Cells were cultured as Panel A and treated with Sandoz 58035 $(4 \mu \mathrm{M})$ and Mevinolin $(0.5 \mu \mathrm{M})$. Three hours before harvesting macrophages were incubated for $3 \mathrm{hrs}$ with $185 \mathrm{kBq} / \mathrm{ml}$ of sodium $\left[{ }^{14} \mathrm{C}\right]$-acetate. At the end of incubation they were harvested and processed as described in Materials and Methods. All incubations were carried out in triplicate and the results expressed as mean \pm S.E.M. ${ }^{*} \mathrm{P}<0.001$ vs control (Newman-Keuls test).

LPS potentiates the rate of cholesterol ester synthesis induced by ac-LDL: As shown in fig. 5, although LPS alone does not influence cholesterol

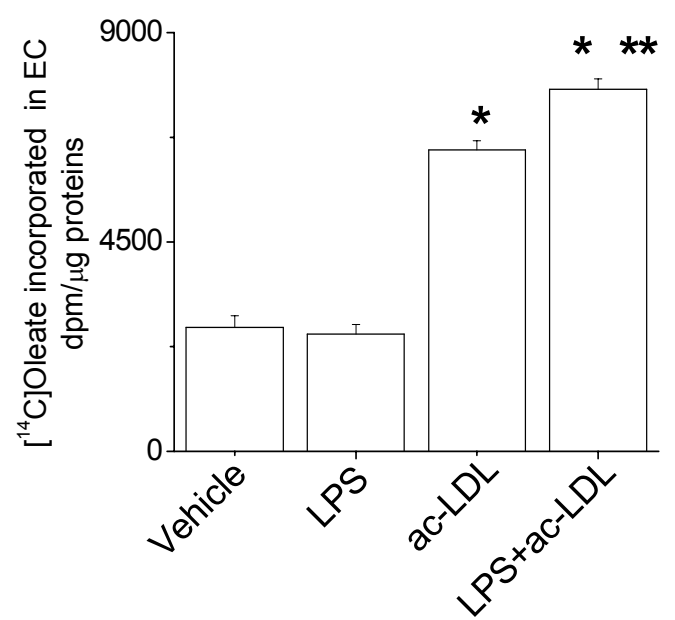

Fig 5: P388D1 cells $\left(2 \times 10^{5} / \mathrm{ml}\right)$ were incubated for $48 \mathrm{hrs}$ in RPMI 1640 medium 10\% FCS. The cells were divided into four groups: vehicle, LPS (100 $\mathrm{ng} / \mathrm{ml})$, ac-LDL $(100 \mu \mathrm{g} / \mathrm{ml})$, LPS + ac-LDL. Four hours before harvesting, $\left[{ }^{14} \mathrm{C}\right]$-oleate was added to the culture medium. At the end of incubation cells were harvested and processed as described in Materials and Methods. Each value represents the mean \pm S.E.M. of triplicate experiments. ${ }^{*} \mathrm{P}<0.001$ vs vehicle; $* * \mathrm{P}<0.05$ vs ac-LDL groups (NewmanKeuls test).

ester synthesis in P388D1 macrophages, it potentiates the increase of cholesterol esterification resulting from the addition of ac-LDL $(\mathrm{P}<0.05)$.

\section{Sandoz 58035 and Mevinolin inhibit cholesterol} esterification in LPS-activated cells: Sandoz 58035 completely inhibited cholesterol esterification (98\% inhibition, $\mathrm{P}<0.001$ ) in activate and LPS-activated cells. A similar effect, even if at minor extent, was observed in Mevinolin treated cells $(\mathrm{P}<0.001)$ (Fig. 6).

Sandoz 58035 and Mevinolin prevent the induction of IL-1 $\beta$ and IL-6 expression in LPS activated macrophages: LPS induced expression of IL-1 $\beta$ and IL-6 in P388D1 cells, this effect being partially prevented by Sandoz 58035 or Mevinolin administration $(\mathrm{P}<0.001)$ (Fig. 7A and B). 


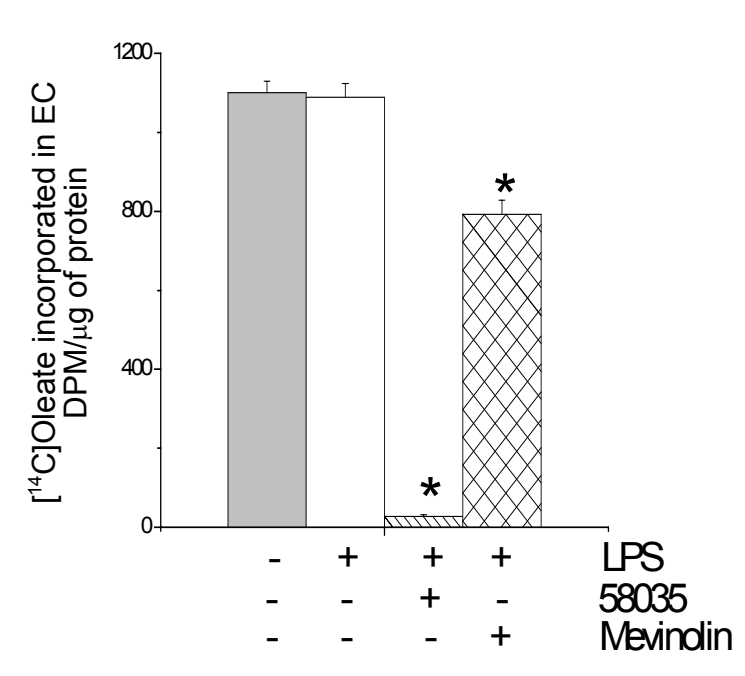

Fig. 6: P388D1 were cultured at $2 \times 105 / \mathrm{ml}$ and incubated for $48 \mathrm{hrs}$ with vehicle, LPS (100 ng/ml), LPS(100 $\mathrm{ng} / \mathrm{ml})+$ Sandoz $58035(4 \mu \mathrm{M})$, LPS $(100 \mathrm{ng} / \mathrm{ml})+$ Mevinolin $(0,5 \mu \mathrm{M})$. Four hours before the end of incubations [14C]-oleate was added to the culture medium. $\left[{ }^{14} \mathrm{C}\right]$-oleate incorporation into esterified cholesterol was determined as described in Materials and Methods. Each value represents the mean \pm S.E.M. of triplicate samples. ${ }^{*} \mathrm{P}<0.001$ and vs control and LPS (Dunnett's test).

\section{DISCUSSION}

Macrophages are the major players of innate immunity not only protecting against microbial infections but also against metabolic antigens, such as modified LDL, recognised as foreign pathogens. They, in fact, possess a large number of receptors for microbial pathogens and numerous tools to destroy them following phagocytosis. Recently it has been demonstrated that the binding of microbial LPS with the Toll like receptors (TLR4), a new family of recognition receptors, activates NF-kappa B, a transcription factor responsible for the synthesis of numerous molecules, including cytokines ${ }^{[11]}$. Modified LDL (oxidised, glycated etc.), considered to have an important part in the atherogenetic process, are also recognised by specific macrophage receptors namely, SRA and SRB. ${ }^{[17-19]}$
A
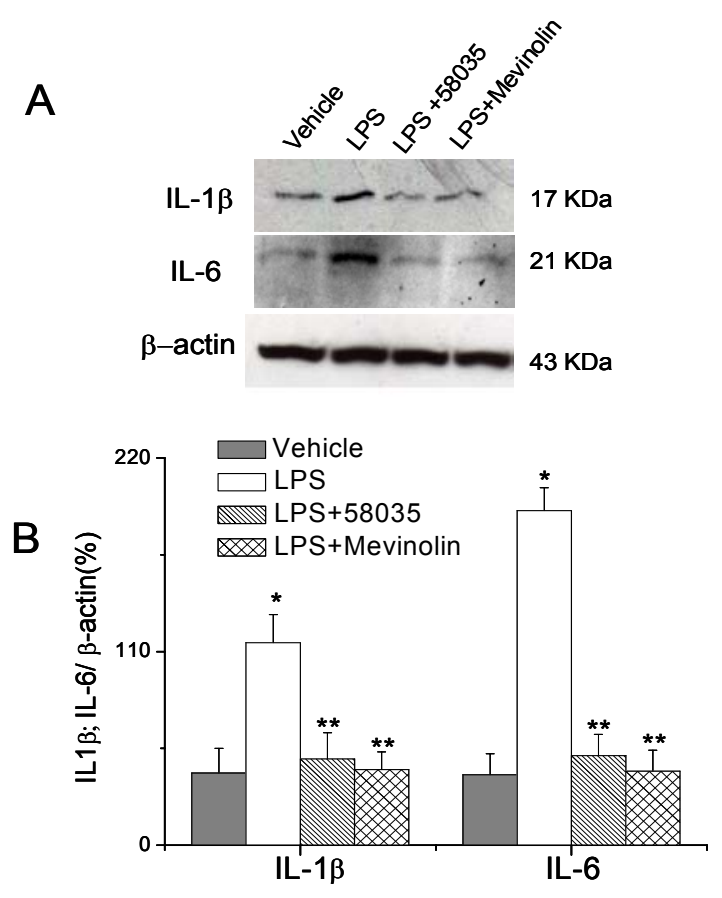

Fig. 7: P388D1 were cultured as in Fig. 6. For protein extraction and western blotting analysis see Materials and Methods (Panel A: autoradiography representative of one experiment). Quantification of the immunoblots were performed by Scion Imagine (Panel B). Each value represents the mean \pm S.E.M. of triplicate samples. $* \mathrm{P}<0.001$ vs control; **P $<0.001$ vs LPS (Dunnett's test).

However, differently from microbial agents, they are not completely degraded following phagocytosis, but hydrolytically processed in lysosomes to generate free cholesterol (FC) and free fatty acids. Since, if in excess, FC may be toxic, it is re-esterified by the ERresident enzyme ACAT and in this form stored in droplets in the cytoplasm. ${ }^{[21]}$ Persistence of high levels of modified LDL coupled with a defective reverse cholesterol transport could thus engulf macrophages that assume the peculiar foam cell shape. Thus, it seems that mechanisms developed by cells to remove metabolic and microbial pathogens initially are similar (i.e receptor pathways) then they diverge to produce cholesterol esters the former and inflammatory 
molecules the latter. In the present study, LPS activation did not change cholesterol synthesis, as well as cholesterol ester synthesis in P388D1 cells. However, cholesterol ester synthesis was remarkably induced only if LPS was combined with ac-LDL. These findings raised the question as to whether in humans, infections should increase cholesterol esterification, leading to foam cell formation, independently from the presence of metabolic risk factors.

Under our experimental conditions, cells growing in presence of sera from statin-treated patients, esterify cholesterol at lower extent than those growing in presence of sera from healthy subjects. On the other hand, STHP was also able to inhibit IL- $1 \beta$ production in LPS-activated cells. This is not a surprise since it has been widely demonstrated that statins inhibit LDL endocytosis and exert an inhibitory effect on Rhomediated inflammatory pathways ${ }^{[13]}$.

In a attempt to establish whether a direct link exists between cholesterol esterification and cytokine production, we next investigated the effect of the ACAT inhibition, on cholesterol esterification and cytokine production in LPS activated P388D1 cells. Interestingly, the almost complete inhibition of cholesterol esterification exerted by Sandoz 58035 was accompanied by a remarkable reduction of cytokine IL-1 $\beta$ and IL-6 production in LPS induced macrophages. The fact that, under our experimental conditions, 58035, differently to statins, did not influence other factors possibly involved in cytokine production (i.e. cell proliferation and cholesterol synthesis) strongly support the hypothesis that cholesterol esterification and cytokine production in macrophages might be in someway related.

However, it remains to explain recent evaluations of ACAT inhibitors indicating that pharmacological inhibition of macrophage ACAT may not reduce, but actually aggravate, foam cell formation and progression It has been suggested that the block of cholesterol esterification could increase free cholesterol into the plaque causing its conversion to an unstable form prone to rupture. ${ }^{[21-24]}$.

However, in vitro studies demonstrated that ACAT inhibitors induces cytokine production only in cholesterol-loaded mouse macrophages ${ }^{[25]}$. Appropriately, our results showed that ACAT inhibition prevents cytokine production following LPS in a non cholesterol-loading condition.
In summary, although preliminary, our data point to a possible relationship between cholesterol esterification and cytokine production in macrophages, prospecting new possible mechanisms by which microbial or inflammatory agents may induce and/or accelerate the atherosclerotic process.

\section{ACKNOWLEDGEMENTS}

We would like to thanks Prof. Sandra Dessì for critically reading the manuscript and fruitful discussion. The study has been funded by Fondazione Banco di Sardegna, Regione Autonoma della Sardegna and Nutrisearch Srl (Italy).

\section{REFERENCES}

1. Moutsopoulos N.M. and Madianos P.N., 2006. Low grade inflammation in chronic infectious diseases: paradigm of periodontal infections. Ann N Y Acad Sci, 1088: 251-264.

2. Wiedermann C.J. et al., 1999. Association of endotoxemia with carotid athrosclerosis and cardiovascular disease: prospective results from the Bruneck Study. J Am Coll Cardiol, 34: 19751981.

3. Espinola-Klein C. et al., 2002. Impact of infectious burden on extent and long-term prognosis of atherosclerosis. Circulation, 105: 1521

4. Koenig W. Khuseyinova N., 2007. Biomarkers of atherosclerotic plaque instability and rupture. Arterioscler Thromb Vasc Biol, 27(1): 15-26.

5. Stoll $\mathrm{G}$ and Bendszus M., 2006. Inflammation and atherosclerosis: novel insights into plaque formation and destabilization. Stroke, 37(7):192332.

6. Vitale G. et al., 2006. Markers of inflammation and infection influence the outcome of patients with baseline asymptomatic carotid lesions: a 5 year follow-up study. Stroke, 37(2): 482-486.

7. Wiedermann C.J. et al., 1999. Association of endotoxemia with carotid atherosclerosis and cardiovascular disease: prospective results from the Bruneck Study. J Am Coll Cardiol, 34(7): 1975-1981.

8. Lehr H-A et al., 2001. Immunopathogenesis of atherosclerosis: endotoxin accelerates atherosclerosis in rabbits on hypercholesterolemic diet. Circulation, 104(8): 914-920.

9. Stoll L.L. et al., 2004. Potential role of endotoxin as a proinflammatory mediator of atherosclerosis. Arterioscl Thromb Vasc Biol, 24(12): 2227-2236. 
10. Arroyo-Espliguero R. et al., 2004. CD14 and tolllike receptor 4: a link between infection and acute coronary events? Heart, 90(9): 983-988.

11. Imler J.L. and Zheng L., 2004. Biology of Toll receptors: lessons from insects and mammals. J Leukoc Biol, 75(1): 18-26.

12. Mahley R.W. and Bersot T.P., 2006. Drug therapy for hypercholesterolemia and dyslipidemia. In: Goodman and Gilman's The Pharmacological Basis of Therapeutics. Brunton et al. eds. McGraw-Hill, New York, pp. 933-966.

13. Mukesh K.J. and Ridker P.M., 2005. Antiinflammatory effects of statins: clinical evidences and basic mechanisms. Nature Reviews, Drug discovery, 4:977-988.

14. Folch J., Lees M., Sloane-Stanley G.H., 1957. A simple method for the isolation and purification of total lipides from animal tissues. J Biol Chem, 222(1): 497-509.

15. Lowry OH et al., 1951. Protein measurement with Folin phenol reagent. J Biol Chem.,193(1):265275.

16. Bradford M.M., 1976. A rapid and sensitive method for the quantitation of microgram quantities of protein utilizing the principle of protein-dye binging. Anal Biochem, 72: 248-254.

17. Ross R., 1993. The pathogenesis of atherosclerosis: a perspective for the 1990s. Nature, 362: 801-809.

18. Ross R., 1999. Atherosclerosis-An inflammatory disease. New Eng J Med, 340(12): 115-126.

19. Libby P., 2002. Inflammation in atherosclerosis. Nature, 420: 868-874.
20. Suckling K. E. and Stange, E. F., 1985. Role of acyl-CoA:cholesterol acyltransferase in cellular cholesterol metabolism. J Lipid Res, 26(6): 647671.

21. Kellner-Weibel G., Jerome W.G., Small D.M., Warner G.J., Stoltenborg J.K., Kearney M.A., Corjay M.H., Phillips M.C. and Rothblat G.H., 1998. Effects of intracellular free cholesterol accumulation on macrophage viability a model for foam cell death. Arterioscler Thromb Vasc Biol, 18 (3): 423-431.

22. Nissen et al., 2006. Effect of ACAT inhibition on the progression of coronary atherosclerosis. N Engl J Med, 354(12): 1253-1263.

23. Stoll G., Bendszus M., 2006. Inflammation and atherosclerosis novel insights into plaque formation and destabilization. Strok, 37(7): 19231932.

24. Tabas I., 2002. Consequences of cellular cholesterol accumulation: basic concepets and physiological implications. J Clin Invest, 110(7): 905-911.

25. Li Y., Schwabe R.F., DeVries-Seimon T., Yao P.M., Gerbod-Giannone M.C., Tall A.R., Davis R.J., Flavell R., Brenner D.A. and Tabas I., 2005. Free cholesterol-loaded macrophages are an abundant source of tumor necrosis factor-alpha and interleukin-6: model of NF-KB and mapkinase-dependent inflammation in advanced atherosclerosis. J Biol Chem, 280(23): 2176321772. 